\title{
The Effect of Training Intensity on Cardiopulmonary Function in 2 Year-Old Thoroughbred Horses
}

\author{
Atsushi HIRAGA ${ }^{1 *}$, Makoto KAI ${ }^{1}$, Katsuyoshi KUBO ${ }^{2}$ and Shigeru SUGANO ${ }^{3}$ \\ ${ }^{1}$ Equine Research Institute, Japan Racing Association, 321-4 Tokami-cho, Utsunomiya, Tochigi 320, 2 Japan \\ Livestock Technology Association, 20-9 Yushima 3-chome, Bunkyo-ku, Tokyo 113, ${ }^{3}$ Department of Comparative \\ Pathophysiology, Division of Veterinary Medical Science, The University of Tokyo, 1-1 Yayoi 1-chome, Bunkyo- \\ $\mathrm{Ku}$, Tokyo 113, Japan
}

We investigated the effect of training intensity difference on cardiorespiratory parameters in twelve 2 year-old Thoroughbred horses during 8 weeks of training (5 days/week). Six horses were trained according to conventional training method including cantering (Canter group), while other 6 horses were exercised only by walking and trotting throughout the same period (Trot group). Each horse performed an incremental exercise test on a treadmill before (Pretest) and after (Post-test) the training period. In the Pre-test, there were no significant differences between the Canter group and the Trot group regarding $\dot{V}_{0_{2 \max }}(154.7 \pm 7.8 \mathrm{ml} / \mathrm{kg} / \mathrm{min}$ in the Canter group, $147.2 \pm 7.5 \mathrm{ml} / \mathrm{kg} / \mathrm{min}$ in the Trot group). After the training period, $\dot{V}_{0_{2 \max }}$ was significantly higher in the Canter group (165.0 $\pm 11.6 \mathrm{ml} / \mathrm{kg} / \mathrm{min})$ compared to the Trot Group (150.3 $\pm 14.7 \mathrm{ml} / \mathrm{kg} / \mathrm{min})$. There were no differences in either group regarding the relationship between HR and speed, or La and speed in the Pre-test. During the Post-test, changes in HR in relation to the speed tended to be lower in Canter group, and La was also slightly lower in this group. Peak values of PCV increased significantly in both groups after the training, however, there were no differences between the groups. These results suggest that even low intensity training such as trotting can maintain $\dot{V} o_{2 \max }$. This indicates that higher intensity training involving cantering is not necessarily required merely to maintain cardiorespiratory function of 2 year-old Thoroughbred in early stage of training. However the findings also indicates that higher intensity training is required to substantially improve cardiorespiratory function in 2 year-old Thoroughbred horses.

Key words: training intensity, young Thoroughbred, $\dot{V} o_{2 \max }$

After breaking, young horses intended to become racehorse are trained in consideration of local climate and available training facilities. In most cases, the initial training is endurance training with submaximal intensity exercise. There have been reports on the effects of submaximal intensity training on the cardiorespiratory function of adult horses $[1,6,10]$. These reports have described an increased maximal oxygen uptake ( $\left.\dot{\mathrm{V}}_{\mathrm{O}_{\text {max }}}\right)$. Other reports on the effects of submaximal intensity training on the cardiorespiratory function of 2 year-old horses in the process of training $[7,14]$, do not clearly demonstrate the effects of various training intensities.

This article was submitted January 28, 1997 and was accepted August 6, 1997.

*corresponding author.
J. Equine Sci.

Vol. 8, No. 3

pp. 75-80, 1997
In the initial stage of training, trotting or cantering is applied to young Thoroughbreds. However, in Hokkaido, the main production area for Thoroughbreds in Japan, the period from breaking to initial training comes during cold and snowy season when it is often difficult to perform endurance training involving cantering. Therefore, it is important to know how the cardiorespiratory parameters of 2 year-old Thoroughbred are affected by differences in training intensities with or without cantering during this period. Although training intensities are usually defined by $\% \dot{\mathrm{V}}_{\mathrm{o}_{\max }}$ or $\% \mathrm{HR}_{\max }$, we regulated training intensities in the present study by using trot or canter according to practical training method in Japan.

In this study, we observed the effects of training intensity differences on cardiorespiratory function by 
comparing training consisting only of trotting and that including cantering.

\section{Materials and Methods}

\section{Horses and training}

Twelve 2 year-old Thoroughbred horses were used in this study (Table 1). All horses were broken to handling and riding in November of their yearling year and then trained in a riding hall ( $40 \mathrm{~m}$ square) at the trot and slow canter until the end of December. From January of their 2 year-old year, 8 weeks of training were performed, 6 horses were trained according to the conventional training schedule described in Table 2 (Canter group). Speed of cantering was increased gradually throughout the training period. At the final stage of training, the horses could canter about $1000 \mathrm{~m}$ at a speed of $800 \mathrm{~m}$ / min. The other 6 horses were exercised with approximately $10 \mathrm{~min}$ of trot (about $2000 \mathrm{~m}$ ) and $30 \mathrm{~min}$ of walk throughout the same 8 week period (Trot group). All horses were exercised 5 days per week, and were pastured about 7 hours/day for the other 2 days. The feeding regime was the same for both groups throughout the study. Heart rate (HR) during the training was monitored at the 8th week of the training period by using HR monitor (Bandage-XL, Pollar, Finland).

\section{Exercise test and parameters}

The exercise tests were performed before (Pre-test) and after the training period (Post-test) on the treadmill (Mustang-2200, Kagra, Switzerland). Prior to exercise testing, all horses were acclimatized to exercise on the treadmill while wearing a respiratory gas collection mask. A standardized exercise protocol was used. Following 5 min of level trotting at $4.0 \mathrm{~m} / \mathrm{s}$ (Warm-up) and $5 \mathrm{~min}$ rest, each horse began the exercise test at $1.8 \mathrm{~m} / \mathrm{s}$ for 1 min, followed by $1 \mathrm{~min}$ step increments at $2.7,3.4,4.5$, $5.4,6.8,9.0,10.8$, and $11.6 \mathrm{~m} / \mathrm{s}$ with the treadmill inclined to $10 \%$ [12]. The exercise test was terminated when it was obvious that the horse could not maintain its position without assistance from the holder. After completion of incremental exercise, the horse was walked $1.0 \mathrm{~m} / \mathrm{s}$ for $15 \mathrm{~min}$ at the same incline $(10 \%)$.

Measurements of $\mathrm{O}_{2}$ uptake $\left(\dot{\mathrm{V}}_{2}\right)$ and $\mathrm{CO}_{2}$ production $\left(\dot{\mathrm{V}} \mathrm{CO}_{2}\right)$ were performed continuously during the exercise test using a bias flow ventilatory system for horses calibrated at each exercise test [4]. HR was monitored continuously with a HR monitor and calculated during the last $30 \mathrm{~s}$ at each step.

Prior to the exercise test, an intravenous catheter was aseptically inserted into the left jugular vein and secured by suture. The catheter was flushed regularly with heparinized saline to maintain patency throughout the exercise test. Blood samples were collected via this catheter during the last $15 \mathrm{~s}$ of each step for measurements of blood lactate concentration (La) and packed cell volume (PCV). La was measured using an automated blood lactate analyzer (YSI-1500 Sport, Yellow Spring Instruments, Ohio). PCV was measured by the micro-hematocrit

Table 1. Experimental horses

\begin{tabular}{lccccc}
\hline & \multicolumn{2}{c}{ Pre } & & \multicolumn{2}{c}{ Post } \\
\cline { 2 - 3 } \cline { 5 - 6 } & Age (month) & Body weight $(\mathrm{kg})$ & & Age (month) & Body weight $(\mathrm{kg})$ \\
\hline Canter group & $21.7 \pm 0.7$ & $449.2 \pm 32.6$ & & $23.6 \pm 0.6$ & $439.4 \pm 24.7$ \\
Trot group & $21.5 \pm 1.1$ & $461.3 \pm 45.7$ & & $22.5 \pm 1.1$ & $470.5 \pm 45.1$ \\
\hline
\end{tabular}

Mean \pm SD

Table 2. Training Program (Canter group)

\begin{tabular}{lll}
\hline December & Indoor wood-tip course $(1000 \mathrm{~m})$ & W-2200 m, T-1200 m, C-1000 m (5 days/week) \\
January & Indoor wood-tip course $(1000 \mathrm{~m})$ & W-2000 m, T-1400 m, C-2000 m (4 days/week) \\
& Indoor dirt course $(600 \mathrm{~m})$ & W-3700 m, T-1300 m, C-2000 m (1 day /week) \\
\multirow{2}{*}{ February } & Indoor wood-tip course $(1000 \mathrm{~m})$ & W-2000 m, T-1400 m, C-2000 m (2 days/week) \\
& Indoor dirt course $(600 \mathrm{~m})$ & W-3700 m, T-1300 m, C-2000 m (3 days/week) \\
\multirow{3}{*}{ March } & Indoor wood-tip course $(1000 \mathrm{~m})$ & W-2000 m, T-1400 m, C-2000 m (1 day /week) \\
& Indoor dirt course $(600 \mathrm{~m})$ & W-3700 m, T-1400 m, C-2400 m (2 days/week) \\
& Indoor dirt course $(600 \mathrm{~m})$ & W-3400 m, T-1100 m, C-1800 m (1 day /week) \\
\hline
\end{tabular}

W: walk, T: trot, C: canter 
method. Data from Pre and Post test were compared by analysis of variance for repeated measurements $(\mathrm{p}<0.05)$. The results were presented as mean \pm S.D.

\section{Results}

HR during exercise at the 8th week of training period was $190-210$ beats/min when the speed was about 600 $\mathrm{m} / \mathrm{min}$ in the Canter group, on the other hand, the HR was $110-120$ beats/min in the Trot group. After the training period, the mean body weight in the Canter group was decreased about $10 \mathrm{~kg}$, while in the Trot group, about $10 \mathrm{~kg}$ increase in the mean body weight was observed (Table 1).

In the Pre-test, there were no significant differences between Canter group and Trot group regarding mean $\dot{\mathrm{V}}_{\mathrm{O}_{\text {2max }}}(154.7 \pm 7.8 \mathrm{ml} / \mathrm{kg} / \mathrm{min}, 147.2 \pm 7.5 \mathrm{ml} / \mathrm{kg} / \mathrm{min}$, respectively; Fig. 1). After the 8 weeks of training, $\dot{\mathrm{V}}_{\mathrm{O}_{\text {max }}}$ had increased in both group but was significantly higher for the Canter group $(165.0 \pm 11.6 \mathrm{ml} / \mathrm{kg} / \mathrm{min})$ than the Trot group (150.3 $\pm 14.7 \mathrm{ml} / \mathrm{kg} / \mathrm{min}$ : Fig. 1). There were no significant differences regarding the $\dot{\mathrm{V}}_{\mathrm{O}_{2} \text {-speed }}$ relationship in either of the groups or in either of the tests (Fig. 2).

There were no difference in either group regarding the relationships between HR and speed, or La and speed in the Pre-test (Figs. 3, 4). On the other hand, changes in HR in relation to the speed tended to be lower in Canter

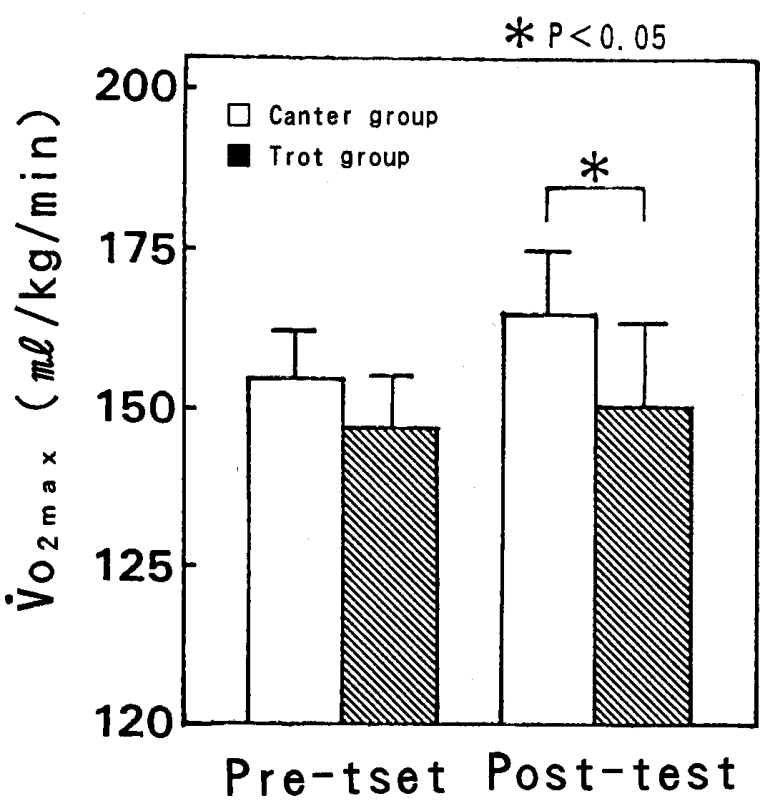

Fig. 1. Changes in $\dot{\mathrm{V}}_{\mathrm{O}_{\text {max }}}$ during training. group, and La was also slightly lower in this group (Figs. 3 , 4). Peak values of $\mathrm{HR}$ and La obtained during exercise test were not significantly different between two groups or between the two tests (Table 3).

In the Pre-test, peak values of PCV during the exercise test was not significantly different between the two groups. After the training, peak values of PCV increased significantly in both groups, however, there was no difference between the groups (Table 3).

\section{Discussion}

Cardiorespiratory function was compared between the Canter group, in which the conventional training including cantering was carried out, and the Trot group, in which training consisted only of walking and trotting was conducted during the same period. Based on HR measured during training, it was inferred that exercise at an intensity of $80-90 \% \mathrm{HR}_{\max }$ was carried out at least 1-2 times per week in the Canter group. In the Trot group, the intensity of exercise was considered to be approximately $40 \% \mathrm{HR}_{\max }$ throughout the same period.

Knight $e t$ al. [10] compared the effects of training at $40 \% \dot{\mathrm{V}}_{\mathrm{o}_{\text {max }}}$ and $80 \% \dot{\mathrm{V}}_{\mathrm{o}_{\text {max }}}$ intensities on adult horse

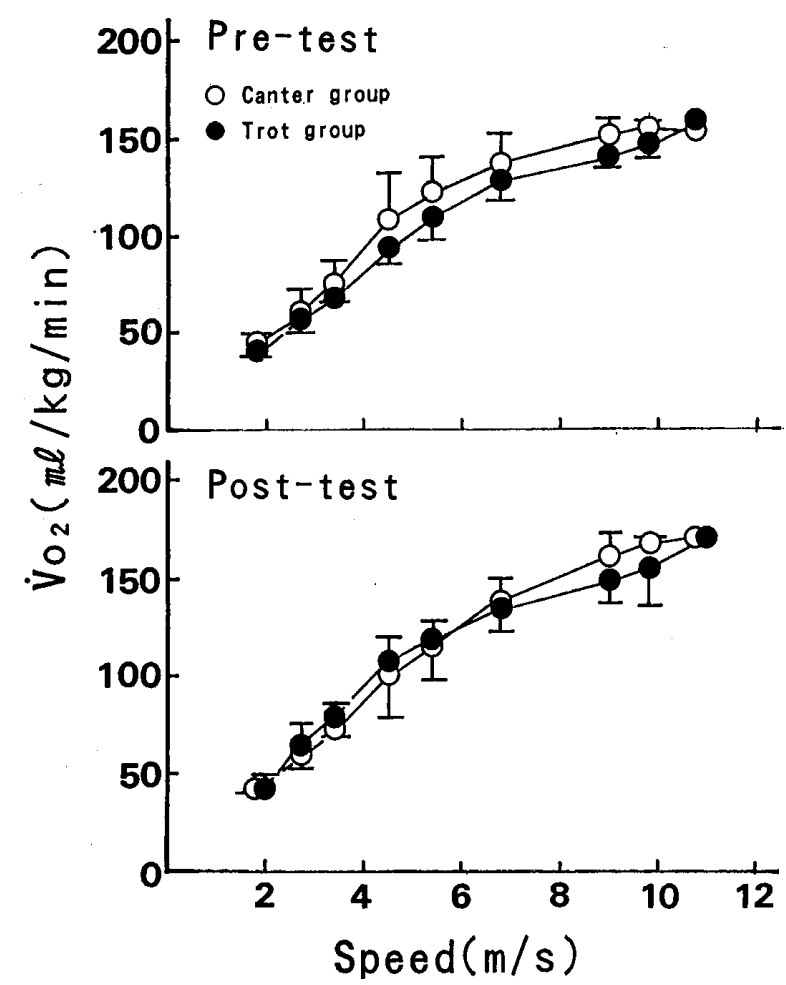

Fig. 2. Mean $\mathrm{O}_{2}$ uptake ( $\dot{\mathrm{V}}_{2} \pm$ S.D.) as a function of speed. 


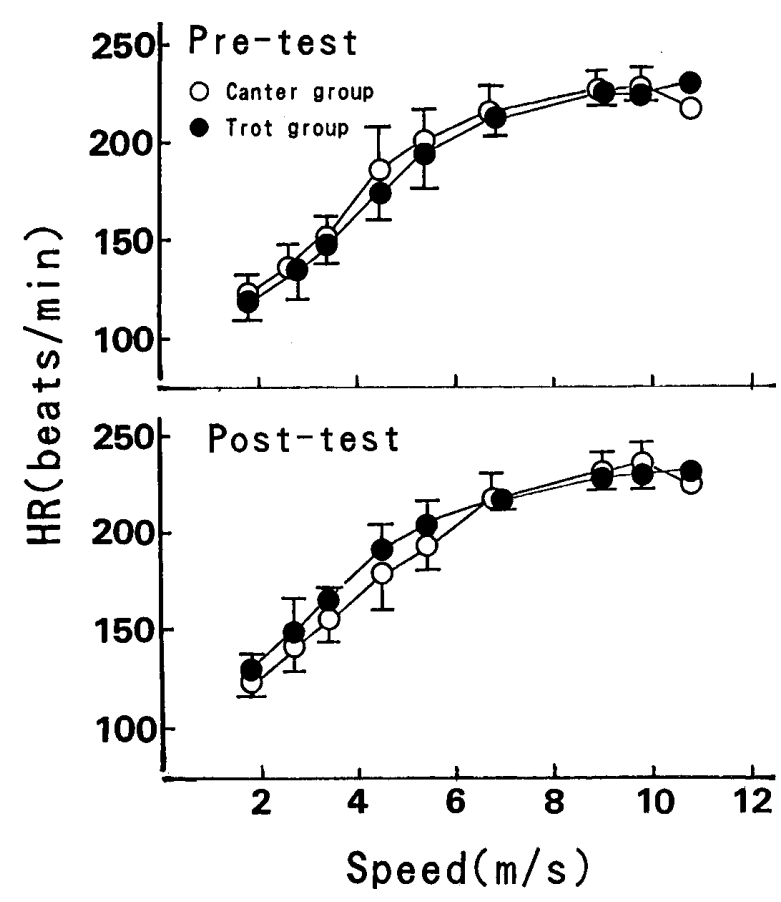

Fig. 3. Mean heart rate (HR \pm S.D. $)$ as a function of speed.

and reported that the increase in $\dot{\mathrm{V}}_{\mathrm{o}_{2 \max }}$ was similar for both groups. This indicates that low intensity training

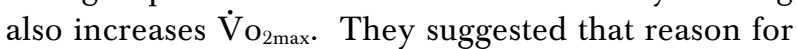
the lack of difference in the increase in $\dot{\mathrm{V}}_{\mathrm{O}_{\text {max }}}$ between $40 \% \dot{\mathrm{V}}_{\mathrm{o}_{2 \max }}$ and $80 \% \dot{\mathrm{V}}_{\mathrm{O}_{\text {max }}}$ intensities was the influence of the correlation between the intensity of the exercise and duration of the exercise. In our study, the $\dot{V}_{o_{2 \max }}$ after training was significantly higher in the Canter group, indicating that training involving cantering at $80-90 \%$ $\mathrm{HR}_{\text {max }}$ intensity, which was used in Canter group, was most effective. Art and Lekeux [1] found that only lowintensity aerobic training induced no significant change in $\dot{\mathrm{V}}_{\mathrm{O}_{2 \max }}$, but that a subsequent three week period of high intensity interval training induced a substantial and significant change. The results of present study support these findings that training of a sufficiently high intensity induces a significant physiological change. In a previous study, the effect of difference in the distances of cantering on cardiorespiratory function, during which a heart rate is approximately $140-150$ beats/min, was examined among Thoroughbreds at the same age. It was found that prolonged distances of low intensity cantering had little effect on the increase in $\dot{V}_{O_{2 \max }}[7]$. In the present study, the training intensity used in the Canter group was much higher than in the previous study [7], which may have contributed to the substantial increase in $\dot{\mathrm{V}}_{\mathrm{O}_{\max }}$.

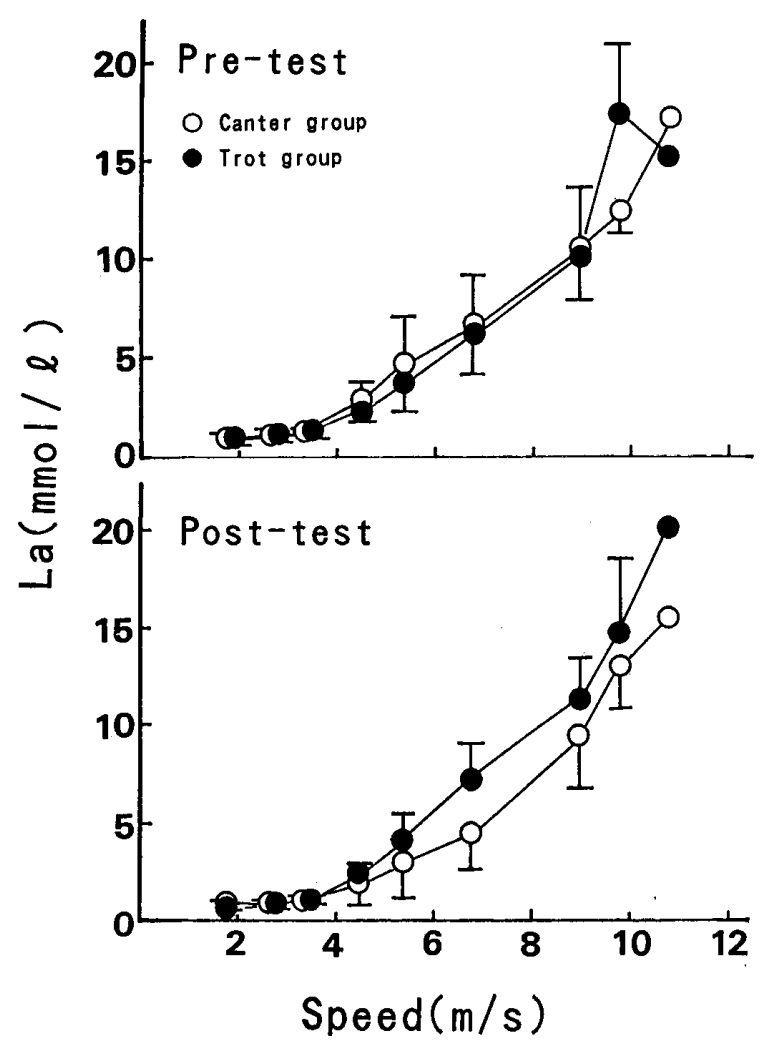

Fig. 4. Mean blood lactate concentration (La \pm S.D.) as a function of speed.

In this study, $\dot{\mathrm{V}}_{\mathrm{O}_{\max }}$ was significantly higher in the Canter group than in the Trot group at the Post-test, and the rate of increase in $\dot{\mathrm{V}}_{\mathrm{O}_{\text {max }}}$ of Canter group (6.7\%) was higher than that of Trot group (2.1\%). However, these increases were lower than those found in previous studies $[1,6,10]$. One possible reason of this is that the horses in this study were not detrained horses, but were young and in the process of training. The Pre-test $\dot{V}_{o_{2 \max }}$ value for horses in this study was similar to that for Thoroughbreds at the same age [7], but higher than that for detrained adult horses [6].

In the Trot group, in which the exercise intensity was approximately $40 \% \mathrm{HR}_{\max }$ throughout the training period, $\dot{\mathrm{V}}_{\mathrm{O}_{2 \max }}$ was virtually unchanged. This differs from the results of a previous study in which there was a significant increase in $\dot{\mathrm{V}}_{\mathrm{O}_{\max }}$ during the first 2 weeks of training at an intensity of $40 \% \dot{\mathrm{V}}_{\mathrm{O}_{\text {max }}}$ [10]. This may have been partly due to the difference in the Pre-test $\dot{\mathrm{V}}_{\mathrm{O}_{\text {max }}}$ value. In other words, through the exercise during the breaking process before the Pre-test, our horses may have already experienced the increased $\dot{\mathrm{V}}_{\mathrm{O}_{\text {max }}}$ which was observed during breaking period in the Thoroughbred yearlings [8]. The results of this study 
Table 3. Peak values during exercise test

\begin{tabular}{|c|c|c|c|c|}
\hline \multicolumn{3}{|c|}{ Parameters (unit) } & \multirow{2}{*}{$\begin{array}{c}\text { Pre } \\
69.4 \pm 4.8 \\
(64.9-79.4)\end{array}$} & \multirow{2}{*}{$\begin{array}{c}\text { Post } \\
71.5 \pm 2.5 \\
(68.4-75.6)\end{array}$} \\
\hline$\dot{\mathrm{V}} \mathrm{o}_{2}$ & $(1 / \mathrm{min})$ & $\begin{array}{c}\text { Canter group : } \\
\text { Range }\end{array}$ & & \\
\hline & & $\begin{array}{c}\text { Trot group : } \\
\text { Range }\end{array}$ & $\begin{array}{l}68.8 \pm 5.1 \\
\quad(62.1-76.0)\end{array}$ & $\begin{array}{l}70.3 \pm 4.9 \\
\quad(66.9-76.9)\end{array}$ \\
\hline \multirow[t]{2}{*}{$\dot{V}_{\mathrm{o}_{2}}$} & $(\mathrm{ml} / \mathrm{kg} / \mathrm{min})$ & $\begin{array}{c}\text { Canter group : } \\
\text { Range }\end{array}$ & $\begin{array}{l}154.7 \pm 7.1 \\
\quad(141.2-164.3)\end{array}$ & $\begin{array}{l}165.0 \pm 10.4 \\
\quad(145.8-176.0)\end{array}$ \\
\hline & & $\begin{array}{r}\text { Trot group } \\
\text { Range }\end{array}$ & $\begin{array}{l}147.2 \pm 6.7 \\
\quad(138.4-158.8)\end{array}$ & $\begin{array}{l}150.3 \pm 13.4 \\
\quad(136.2-173.6)\end{array}$ \\
\hline \multirow[t]{2}{*}{$\dot{\mathrm{V}} \mathrm{co}_{2}$} & $(1 / \mathrm{min})$ & $\begin{array}{c}\text { Canter group : } \\
\text { Range }\end{array}$ & $\begin{array}{l}90.2 \pm 4.5 \\
\quad(84.6-97.0)\end{array}$ & $\begin{array}{l}90.8 \pm 4.6 \\
\quad(85.4-97.4)\end{array}$ \\
\hline & & $\begin{array}{c}\text { Trot group } \\
\text { Range }\end{array}$ & $\begin{array}{l}90.5 \pm 7.3 \\
\quad(78.6-97.8)\end{array}$ & $\begin{array}{l}90.3 \pm 6.6 \\
\quad(82.7-99.7)\end{array}$ \\
\hline \multirow[t]{2}{*}{$\dot{\mathrm{V}} \mathrm{CO}_{2}$} & $(\mathrm{ml} / \mathrm{kg} / \mathrm{min})$ & $\begin{array}{c}\text { Canter group : } \\
\text { Range }\end{array}$ & $\begin{array}{l}201.6 \pm 11.6 \\
\quad(181.4-214.2)\end{array}$ & $\begin{array}{l}209.5 \pm 15.4 \\
\quad(182.7-220.4)\end{array}$ \\
\hline & & $\begin{array}{c}\text { Trot group } \\
\text { Range }\end{array}$ & $\begin{array}{r}193.8 \pm 13.0 \\
\quad(187.1-216.4)\end{array}$ & $\begin{array}{l}192.9 \pm 17.7 \\
(166.4-221.7)\end{array}$ \\
\hline \multirow[t]{2}{*}{ HR } & (beats/min) & $\begin{array}{c}\text { Canter group : } \\
\text { Range }\end{array}$ & $\begin{array}{l}228.4 \pm 8.1 \\
\quad(217.3-234.3)\end{array}$ & $\begin{array}{l}234.3 \pm 9.4 \\
\quad(224.8-250.0)\end{array}$ \\
\hline & & $\begin{array}{r}\text { Trot group } \\
\text { Range }\end{array}$ & $\begin{array}{l}230.1 \pm 6.7 \\
\quad(221.7-238.0)\end{array}$ & $\begin{array}{l}230.3 \pm 5.9 \\
\quad(220.2-236.0)\end{array}$ \\
\hline \multirow[t]{2}{*}{$\mathrm{La}$} & $(\mathrm{mmol} / \mathrm{l})$ & $\begin{array}{c}\text { Canter group : } \\
\text { Range }\end{array}$ & $\begin{array}{l}18.5 \pm 2.8 \\
\quad(14.21-22.75)\end{array}$ & $\begin{array}{l}17.1 \pm 2.3 \\
\quad(14.51-20.16)\end{array}$ \\
\hline & & $\begin{array}{c}\text { Trot group : } \\
\text { Range }\end{array}$ & $\begin{array}{l}21.1 \pm 4.3 \\
\quad(14.59-22.97)\end{array}$ & $\begin{array}{l}17.6 \pm 5.3 \\
\quad(9.38-23.94)\end{array}$ \\
\hline \multirow[t]{2}{*}{$\mathrm{PCV}$} & $(\%)$ & $\begin{array}{c}\text { Canter group : } \\
\text { Range }\end{array}$ & $\begin{array}{l}55.4 \pm 2.7 \\
\quad(51.0-59.0)\end{array}$ & $\begin{array}{l}58.2 \pm 3.0 \\
\quad(53.0-61.0)\end{array}$ \\
\hline & & $\begin{array}{c}\text { Trot group } \\
\text { Range }\end{array}$ & $\begin{array}{l}55.7 \pm 2.6 \\
\quad(53.0-59.0)\end{array}$ & $\begin{array}{l}58.0 \pm 4.0 \\
\quad(52.0-65.0)\end{array}$ \\
\hline
\end{tabular}

show that the $\dot{\mathrm{V}}_{\mathrm{O}_{\max }}$ of Thoroughbreds at this age cannot be increased, but can be maintained by continuing trotting at a $40 \% \mathrm{HR}_{\max }$ intensity.

It has been suggested that there is close relationship between increases in the peak values of $\dot{\mathrm{V}}_{\mathrm{o}_{2}}$ and peak values of PCV [12]. In this study, the peak values of PCV was increased through training, but no difference was found between the two groups. In addition, the absolute value of $\dot{V}_{o_{2 \max }}(1 / \mathrm{min})$ was similar for the two groups, and increased after the test. On the other hand, mean body weight decreased in the Canter group but increased in the Trot group, partly because the diets for both groups were the same. These different changes in body weight between the two groups may have made a substantial contribution to the Post-test significant difference in relative value of $\dot{\mathrm{V}}_{\mathrm{O}_{\max }}(\mathrm{ml} / \mathrm{kg} / \mathrm{min})$.

Although the difference between groups was not significant, the relationship between speed and HR was slightly lower in the Canter group than in the Trot group. This resemble the effect of training on yearlings [11], and that of submaximal training on adult horses [6]. The correlation between speed and La at the Post-test tended to be lower in the Canter group. All of these findings suggest the improved cardiorespiratory function of the Canter group.

The result of present study showed some important points concerning the actual training of young Thoroughbreds of this age. First, even low intensity

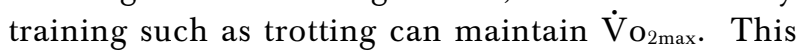
indicates that higher intensity training is not necessarily required merely to maintain cardiorespiratory function of 2 year-old Thoroughbreds in early stage of training. However, the findings also indicates that higher intensity training involving cantering is required to substantially improve cardiorespiratory function. A previous study showed that it is important for racehorses to increase their tolerance for exercise of the muscle [5], bone and tendon $[2,9]$ through higher intensity training. The results of our study may support these findings. 


\section{Acknowledgments}

The authors thank and acknowledge the dedicated effort of the members of Hidaka Yearling Training Farm, Japan Racing Association.

\section{References}

1. Art, T. and Lekeux, P. 1993. Training-induced modifications in cardiorespiratory and ventilatory measurements in Thoroughbred horses. Equine Vet. J. 25: 532-536.

2. Buckingham, S.H.W. and Jeffcott, L.B. 1987. Changes in bone strength and density in Standardbreds from weaning to onset of training. pp. 631-643. In: Equine Exercise Physiology 2 (Gillespie, J.R. and Robinson, N.E. eds.), ICEEP Publications, Davis, CA.

3. Butler, P.J., Woakes, A.J., Anderson, L.S., Smale, K., Roberts, C.A. and Snow, D.H. 1991. The effect of cessation of training on cardiorespiratory variables during exercise. pp. 71-76. In: Equine Exercise Physiology 3 (Persson, S.G.B., Lindholm, A. and Jeffcott, L.B. eds.), ICEEP Publications, Davis, CA.

4. Erickson, B.K., Seaman, J., Kubo, K., Hiraga, A., Kai, M., Yamaya, Y. and Wagner, P.D. 1994. Mechanism of reduction in alveolar-arterial $\mathrm{PO}_{2}$ difference by helium breathing in exercising horse. J. Appl. Physiol. 76: 2794-2801.

5. Essen-Gustavson, B., Lindholm, A., McMiken, D., Persson, S.G.B. and Thornton, J. 1983. Skeletal muscle characteristic of young Standardbreds in relation to growth and early training. pp. 200-210. In: Equine Exercise Physiology (Snow, D.H., Persson, S.G.B. and Rose, R.J. eds.), Granta Editions, Cambridge.

6. Evans, D.L. and Rose, R.J. 1988. Cardiovascular and respiratory responses to submaximal exercise training in the thoroughbred horse. Pflugers Arch.
411: 316-321.

7. Hiraga, A., Kai, M., Kubo, K. and Erickson, B.K. 1995. The effect of long slow distance training on aerobic work capacity in young Thoroughbred horses. J. Equine Sci. 6: 1-6.

8. Hiraga, A., Kai, M., Kubo, K. and Sugano, S. 1997. Effects of low intensity exercise during the breaking period on cardiopulmonary function in Thoroughbred yearlings. J. Equine Sci. 8: 21-24.

9. Jeffcott, L.B., Buckingham, S.H.W. and McCartney, R.N. 1987. Noninvasive measurements of bone quality in horses and changes associated with exercise. pp. 615-630. In: Equine Exercise Physiology 2 (Gillespie, J.R. and Robinson, N.E. eds.), ICEEP Publications, Davis, CA.

10. Knight, P.K., Sinha, A.K. and Rose. R.J. 1991. Effects of training intensity on maximum oxygen uptake. pp. 77-88. In: Equine Exercise Physiology 3 (Persson, S.G.B., Lindholm, A. and Jeffcott, L.B. eds.), ICEEP Publications, Davis, CA.

11. Persson, S.G.B., Essen-Gustavson, B., Lindholm, A., McMiken, D. and Thornton, J.R. 1983. Cardiorespiratory and metabolic effects of training of Standardbred yearlings. pp. 458-469. In: Equine Exercise Physiology (Snow, D.H., Persson, S.G.B. and Rose, R.J. eds.), Granta Editions, Cambridge, UK.

12. Seeherman, H.J. and Morris, E.A. 1990. Application of a standardized treadmill exercise test for clinical evaluation of fitness in 10 Thoroughbred race horses. Equine Vet.J. Suppl. 9: 26-34.

13. Seeherman, H.J. and Morris, E.A. 1991. Comparison of yearling, two-year-old and adult Thoroughbreds using standardized exercise test. Equine Vet.J. 23: 175-184.

14. Sexton. W.L., Erickson, H.H. and Coffman, J.R. 1987. Cardiopulmonary and metabolic responses to exercise in the Quarter horse: Effect of training. pp. 77-91. In: Equine Exercise Physiology 2 (Gillespie, J.R., and Robinson, N.E. eds.), ICEEP Publications, Davis, CA. 